\title{
ポーラスコンクリートの振動締固めに関する実験的研究 EXPERIMENTAL STUDY ON THE COMPACTION WITH VIBRATION FOR POROUS CONCRETE
}

湯 浅 幸久*，畑 中重 光**，三島直生***，前川明弘****，宮本高秀*****

Yukihisa YUASA, Shigemitsu HATANAKA, Naoki MISHIMA, Akihiro MAEGAWA and Takahide MIYAMOTO

\begin{abstract}
In the production of porous concrete, it was confirmed that the flowability of the cement paste is stabilized by mixing for more than 270 seconds irrespective of the kind of chemical admixture. However, the use of superplasticizer influences water cement ratio and compressive strength which is suitable for porous concrete. In the compaction by surface vibrator for porous concrete, there was a difference of about $10 \%$ of void ratio between the upper and lower layers. It became clear that a suitable flow value for optimum performance of porous concrete is influenced by the value of a designed void ratio. The compressive strength of porous concrete is able to be estimated by the void ratio and the compressive strength of concrete without void when same binder is used.
\end{abstract}

Keywords: Porous concrete, Flowability, Compaction with vibration, Void ratio, Compressive strength ポーラスコンクリート、流動性、振動締固め、空隙率、圧縮強度

\section{1.はじめに}

ポーラスコンクリートの研究が本格化して十数年になる。この 間、ポーラスコンクリートの強度を支配する要因として、空隙率、 水セメント比、ペースト(以下、とくにことわらない限りセメント ペーストを指す)粗骨材容量比、骨材粒径などの影響に関する基礎

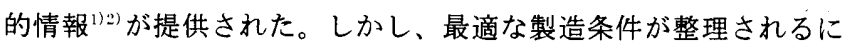
は至っていない。その理由は、通常のコンクリートが水や空気を 通さない密実な材料であるのに対して、ポーラスコンクリートは 調合上の空気量（ここでは空隙率）を大きく設定することで連続 した空隙を形成させることが大きな特徵となっでおり、その空陌 構造の形成方法や強度保持のメカニズムが通常のコンクリートと は著しく異なるためである。

ポーラスコンクリートに求められる連続空隙量および十分な強 度性能を確保するためには、ペース卜部分が高強度であることは もちろんのこと、玉井 ${ }^{3)}$ や吉森ら ${ }^{4)}$ が提唱する Funicular の第 1 領域 の確保、すなわち連続した空隙を保持した状態で、骨材間を架橋 するペーストの連続性が確保されることが重要な条件となる。し たがって、ペーストの流動性がポーラスコンクリートの性能を左 右することは明らかである。筆者らが行った基礎実験では、ミキ
サの性能（練混ぜ機構の違い）や練混ぜ時間によってもポーラス コンクリートに適した低水セメント比におけるペーストの性状は 異なることが分かっている5 。

ペーストの流動性に着目した既往の研究では、玉井 ${ }^{3)}$ がレオロ ジ一量（降伏值および塑性粘度）について触れているものの、他 の多くの研究者が、より簡易な試験方法であるフローテーブル試 験機により測定したフロー值とポーラスコンクリートの強度の関 係に着目しており、最適なフロー値として $180^{6)} 、 190^{71} 、 200^{81} 、 230^{91}$ 、 $240^{10)} 、 280^{11}$ などが提案されている。しかしながら、減水剤の使 用の有無や練混ぜ条件、締固め条件などが異なるため、これらの 值を単純には比較できない。今後は、このように異なる条件下で 提案されたペーストの流動性について、レオロジー量の変動を調 ベることで、ポーラスコンクリートに適したペーストのフレッシ ユ性状を系統的に把握する必要がある。さらに、施エによる変動 をも予測するため、締固めまでの一連の過程を考慮した検討が必 要である。

そこで本研究では、ポーラスコンクリートの製造に最適な材料 ・施工条件を整理することをを目的として、まずポーラスコンクリ ートに適したペーストのフレッシュ性状を定量的に調べる。次に

\footnotetext{
* 三重大学大学院工学研究科システム工学尃攻 大学院生

** 三重大学工学部建築学科 教授. 工博

*** 三重大学工学部建築学科 助手·王博

**** 三重県科学技術振興センター工業研究部 研究員

***** 三重大学大学院工学研究科建築学専攻 大学院生
}

Graduate Student, Div. of Systems Engineering, Graduate School of Engineering, Mie University

Prof., Dept. of Architecture, Faculty of Engineering, Mie University, Dr. Eng.

Research Assoc., Dept. of Architecture, Faculty of Engineering, Mie University, Dr. Eng.

Div. of Industrial Research, Mie Pref. Science and Technology Promotion Center Graduate Student, Dept. of Architecture, Graduate School of Engineering, Mie University 
ポーラスコンクリートの製造時の重要な要因となる振動締固め性 状についてペーストのフレッシュ性状と関連づけて検討する。

\section{2. 実験方法}

\section{1 使用材料}

使用した材料の種類と特性值を表 1 に示す。セメントには、比 表面積等の物理特性が安定して供給されるセメント協会製研究用 セメント(記号：C)を使用した。粗骨材には、単粒度砕石 6 号(記 号：G）を使用した。混和剤には、リグニンスルホン酸塩系減水剂 (記号：A)扔よびポリカルボン酸系高性能 $\mathrm{AE}$ 減水剤(記号: Sp) を使用した。ここで、減水剤は通常 $\mathrm{AE}$ 剂とともに用いるが、多 量の気泡発生によるフロー值への影響を避けるため、 $\mathrm{AE}$ 㓮は添 加しないことにした。またポリカルボン酸系高性能 $\mathrm{AE}$ 減水剂は、 減水剂そのものが骨材等の影響で練混ぜ時にエントレインドエア を発生させる働きがあるため、 $\mathrm{AE}$ 剂は添加せず、そのまま使用 した。なお、このときのペースト中の空気量は $1 \%$ 程度であり、 ポーラスコンクリートへの影響は小さいことを確認している。

\section{2 調合条件および練混ぜ条件}

\section{(1)セメントペーストの練混ぜ実験}

ペーストの練混ぜ実験の概要を表 2 に示寸。ペーストの流動性 は, 減水剂の使用条件や練混ぜ条件により異なるため、減水剤の 種類・添加量および水セメント比を勘案し、振動締固めによる既 往の文献 7)8）を参考に、W/C $=20 \sim 36(\%)$ 範囲でフロ一值が 150 〜 230 程度となるよう設定した。ミキ开には, 硬練りに適した練

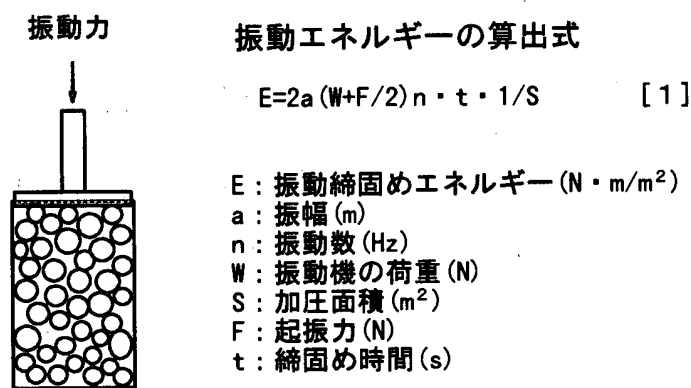

图 1 ポーラスコンクリートの締固め方法 および振動エネルギーの算出式 （JCI超硬練りコンクリート研究委員会報告害 ${ }^{14)}$ の式）
混ぜ性能が得られ，かつ摚汼に伴う骨材の破壊が少ない摇動摚汼 型ミキサ $(30$ に $)$ を使用した5)。練混ぜ方法は，セメントおよび 水を投入後 30 秒間は $50 \mathrm{rpm}$ で，その後所定の時間まで $200 \mathrm{rpm} の$ ミキサ回転数で混練した。

ペーストのフレッシュ性状を定量的に把握するため, フローテ ーブル試験機によりフロー值を、円柱形 7 号ロータ（高粘度用） を取り付けた内円筒回転型粘度計によって粘度をそれぞれ測定し た。粘度測定の場合には, 一般に硬練りペーストでは平板プラス トメータが、軟練りペーストでは球引上げ試験機や傾斜管試験機

\section{表 1 使用材料の種類と特性値}

\begin{tabular}{|c|c|c|c|}
\hline 種 類 & 特 & 值 & 貶昂 \\
\hline セメント & $\begin{array}{c}\text { 研究用セメント(普通ポ } \\
\text { 密度 }\left(\mathrm{g} / \mathrm{cm}^{3}\right) \\
\text { 比表面樻 }\left(\mathrm{cm}^{2} / \mathrm{g}\right)\end{array}$ & $\begin{array}{l}\text { ルトランド) } \\
: 3.17 \\
: 3150\end{array}$ & C \\
\hline 粗骨材 & $\begin{array}{c}\text { 単粒度碎石6号 }(5 \sim 13 \mathrm{~mm} \\
\text { 表乾密度 }\left(\mathrm{g} / \mathrm{cm}^{3}\right) \\
\text { 実樌率 }(\%)\end{array}$ & $\begin{array}{l}n: \text { 佐奈山産) } \\
: 2.70 \\
: 57.4\end{array}$ & G \\
\hline 混和剂 & $\begin{array}{l}\text { 隇水剂 (リグニンスルホ } \\
\text { 高性能AE滅水剂 (ポリカ) }\end{array}$ & $\begin{array}{l}\text { シン酸塩系） } \\
\text { ルボン酸系) }\end{array}$ & $\begin{array}{l}\text { A } \\
\text { Sp }\end{array}$ \\
\hline
\end{tabular}

表 2 ペースト練混ぜ実験の概要

\begin{tabular}{|c|c|c|c|}
\hline 項 目 & 条 & & 壾昂 \\
\hline W/C (\%) & $20 \sim 36$ & & - \\
\hline $\begin{array}{l}\text { 混和剂使用条件 } \\
\text { : 添加量 (\%) } \\
\text { (対セメント量) }\end{array}$ & $\begin{array}{l}\text { 無添加 } \\
\text { 減水剂 (原液換算) } \\
\text { 高性能AE減水剂 } \\
\text { 高性能AE墄水剂 }\end{array}$ & $\begin{array}{l}: 0.25 \\
: 0.5 \\
: 1.0\end{array}$ & $\begin{array}{l}N \\
R \\
L \\
S\end{array}$ \\
\hline 練混ぜ時間 (s) & $90,180,270,360,45$ & & - \\
\hline 測定項目 & フロー值, 粘度 & & - \\
\hline
\end{tabular}

表 4 ポーラスコンクリートの作製条件および測定項目

\begin{tabular}{|c|c|c|}
\hline 練混ぜ方法 & $\begin{array}{l}\text { ミキサ回転数 (rpm) } \\
\text { 練混ぜ時間 (s) }\end{array}$ & 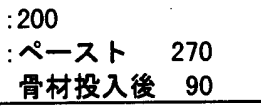 \\
\hline 供試体寸法 & 円柱供試体 (cm) & $: \phi 10 \times 20$ \\
\hline 試料の投入方法 & 1 層詰め & \\
\hline 締固め方法 & $\begin{array}{l}\text { 表面振動機 } \\
\text { 起振力 (N) } \\
\text { 締固め時間 (s) }\end{array}$ & $\begin{array}{l}: 0, \quad 245,735,1225 \\
: 10\end{array}$ \\
\hline 測定項目 & 空吵率、圧縮強度 & \\
\hline
\end{tabular}

《練混ぜフロー》

\begin{tabular}{|c|c|c|}
\hline ペースト練混ぜ & $\rightarrow$ 骨材投入 $\rightarrow$ & 軾料作製 \\
\hline 270秒練混せ & 90秒練混ぜ & 缔固め \\
\hline
\end{tabular}

表 3 ポーラスコンクリートの調合

\begin{tabular}{|c|c|c|c|c|c|c|c|c|c|c|c|}
\hline \multirow{2}{*}{ 減水剂の種類 } & \multirow{2}{*}{$\begin{array}{c}\text { 添加量 } \\
(\%)\end{array}$} & \multirow{2}{*}{ 町 量 } & \multirow{2}{*}{$\begin{array}{c}\text { 設䀦空隙率 } \\
(\%)\end{array}$} & \multirow{2}{*}{$\begin{array}{l}\text { ペースト粗骨 } \\
\text { 材比 (vol\%) }\end{array}$} & \multirow{2}{*}{$\begin{array}{c}\text { 設定 } \\
\text { フロー値 }\end{array}$} & \multirow{2}{*}{$\begin{array}{l}W / C \\
(\%)\end{array}$} & \multicolumn{4}{|c|}{ 単位量 (kg/m³) } & \multirow{2}{*}{$\begin{array}{c}\text { 実測 } \\
\text { フロー值 }\end{array}$} \\
\hline & & & & & & & 水 & セメント & 粗骨材 & 混和刘 & \\
\hline \multirow[b]{2}{*}{ 無添加 } & \multirow[b]{2}{*}{0} & \multirow[b]{2}{*}{ N25 } & \multirow{10}{*}{25} & \multirow{10}{*}{29.7} & 150 & 28.1 & 80 & 286 & \multirow{10}{*}{1550} & & 151 \\
\hline & & & & & 190 & 31.1 & 85 & 273 & & - & 190 \\
\hline \multirow{3}{*}{ 減水剂 } & \multirow{3}{*}{0.25} & \multirow{3}{*}{ R25 } & & & $\frac{200}{150}$ & $\frac{04.1}{26.3}$ & $\frac{05}{78}$ & 295 & & 0.738 & $\frac{2 \angle 0}{150}$ \\
\hline & & & & & 190 & 31.0 & 85 & 273 & & 0.682 & 189 \\
\hline & & & & & 230 & 35.7 & 91 & 254 & & 0.635 & 228 \\
\hline \multirow{3}{*}{ 高性能AE減水剂 } & \multirow{3}{*}{0.5} & \multirow{3}{*}{ L25 } & & & 150 & 23.6 & 73 & 310 & & 1.548 & 151 \\
\hline & & & & & 190 & 25.3 & 76 & 300 & & 1. 502 & 190 \\
\hline & & & & & 230 & 26.9 & 79 & 292 & & 1.460 & 227 \\
\hline \multirow[b]{2}{*}{ 高性能AE隇水剂 } & \multirow[b]{2}{*}{1.0} & \multirow[b]{2}{*}{ S25 } & & & 150 & 21.1 & 68 & 324 & & 3.243 & 147 \\
\hline & & & & & 190 & 22. 0 & 70 & 319 & & 3. 188 & 188 \\
\hline
\end{tabular}


などが適している。しかしながら本実験で設定した流動性の範囲 を同一条件で測定することは難しい。また最近の研究ではせん断 ボックス試験 ${ }^{12)}$ 有効とされているが、本実験では比較的適用範 囲が広いと考えられる回転粘度計を採用することにした。回転粘 度計は、塑性粘度が小さく降伏值が大きい場合に試料と円筒の境 界面で滑りが発生するという指摘 ${ }^{13)}$ もるが、筆者らの研究によ れば、セメントの分散性が十分であれば、ペーストのフレッシュ 性状の傾向を捉えることは可能である ${ }^{7} 。$

ペーストの練混ぜ時間は $90,180,270,360,450$ 秒の 5 段階と した。

\section{(2) ポーラスコンクリートの作製条件}

ポーラスコンクリートの作製に用いるペーストの水セメント比 は、各減水剤の使用条件別の水セメント比とフロ一值の関倸から フロー值が 150、190、230 となるよう設定した。練混ぜ方法は、 ペースト先練りとし、セメントおよび水を投入後 30 秒間はミキサ

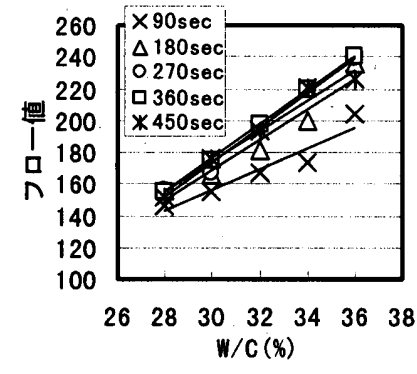

(a) 減水剂無添加

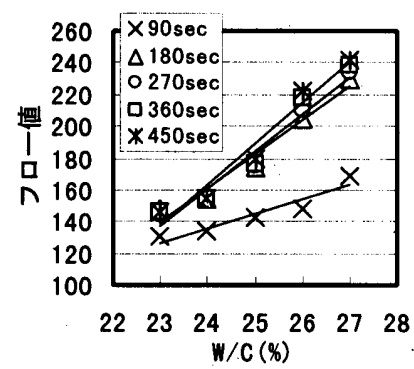

(c) 高性能AE滅水剂 (0.5\%)

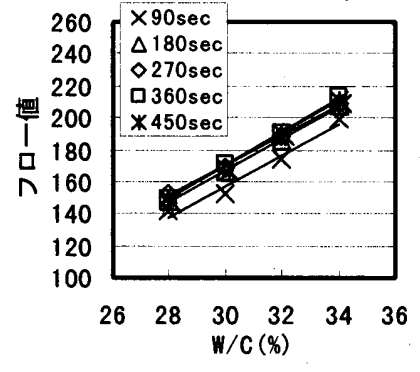

(b) 減水剂 (0.25\%)

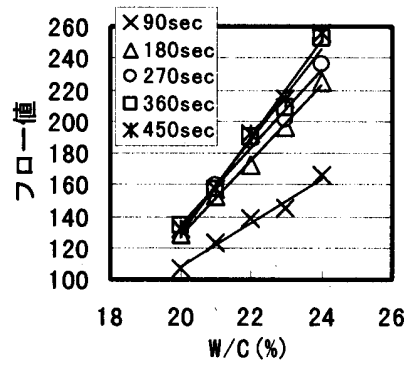

(d) 高性能AE減水剂 (1.0\%)
図 2 混和剤の使用条件が異なるペーストの水セメント比 とフロー值の関係
回転数を $50 \mathrm{rpm}$ で、その後 $200 \mathrm{rpm}$ にしてペーストの流動性が安 定する 270 秒まで練り混ぜた後、骨材を投入してさらに 90 秒間練 り混ぜ、供試体を作製した。調合を表了に、供試体の作製条件お よび測定項目を表 4 にそれぞれ示し、製造過程の説明に練混ぜフ ロー図を付記した。試料の投入方法を 1 層詰めとした理由は、表 面振動機による締固めの程度を上下方向に評価するためである。 振動エネルギーの算出式を图 1 に示す。空隙率の測定はエココン クリート研究委員会報告書「ポーラスコンクリートの空隙率試験 方法（案）」にによった。

\section{3. 実験結果}

3. 1 セメントペーストの性状

\section{(1) 減水刘の使用条件とフロ一值の関係}

図 2 にペーストのフロー值と水セメント比の関係を減水剤の使 用条件（種類と使用量）別に示す。また練混ぜ時間別に近似直線 を付した。図によれば、いずれの減水剤使用条件においても水セ メント比とフロー值のあいだに高い相関があることが分かった。 また練混ぜ時間が概ね 270 秒以上で一定の関倸になる。したがっ て本実験で用いたミキサの場合、ポーラスコンクリートに用いる 低水セメント比ペーストの流動性を安定させるには、少なくとも 5 分程度の練混ぜ時間を確保することが重要である。

減水剤の使用条件の違いを比較するため、図 3 に練混ぜ時問 270 秒における水セメント比とフロー值の関倸を示す。図によれば、 減水剤無添加（N）と減水剂（R）の使用による差は認められな かった。これは通常使用される減水剤が本実験で設定した低水セ メン比では効果がないことを意味している。一方、高性能 AE 減 水剂では、添加量 $(\mathrm{L} 、 \mathrm{~S})$ に応じて、十分な减水効果が得られた。 ただし、水量の変動に対しては敏感である。

\section{（2）減水剂の使用条件と粘性の関係}

ペーストの軟らかさをレオロジー性質で見た場合、時間依存性 を除けばビンガム流体として取り扱うことができる。回転粘度計 による測定結果をもとに算出した降伏值および塑性粘度とフロー 值の関係を図4に示す。図によれば高性能 $\mathrm{AE}$ 減水剤を添加した ペーストは、添加量の増加に伴い降伏値および塑性粘度が増大す る傾向を示した。この傾向はフロー值が小さいほど顕著に現れた。 ペーストのレオロジー量は、直接的には水セメント比の影響を大 きく受けることから、高性能 AE 減水剤を用いて水セメント比を

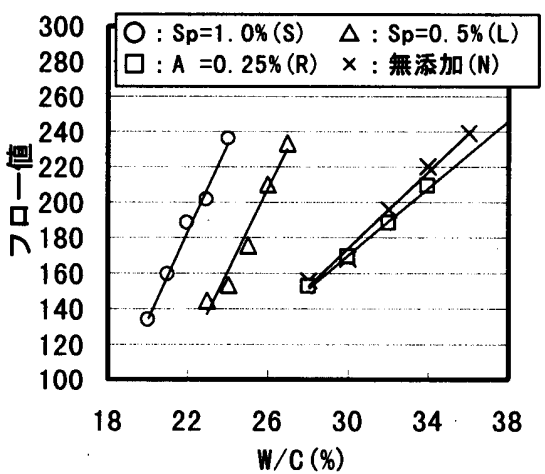

图 3 練混ぜ時間270秒におけるW/Cと フロー値の関係

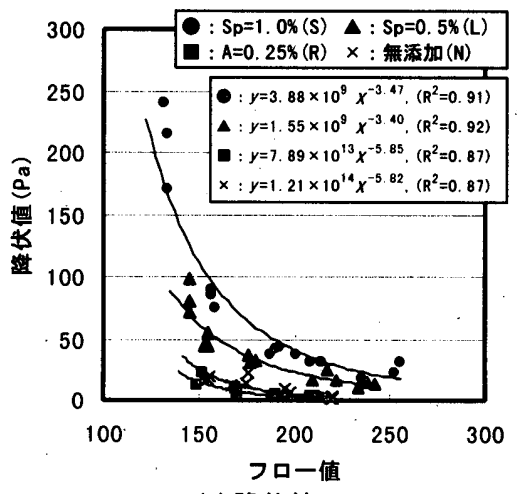

(a) 降伏值

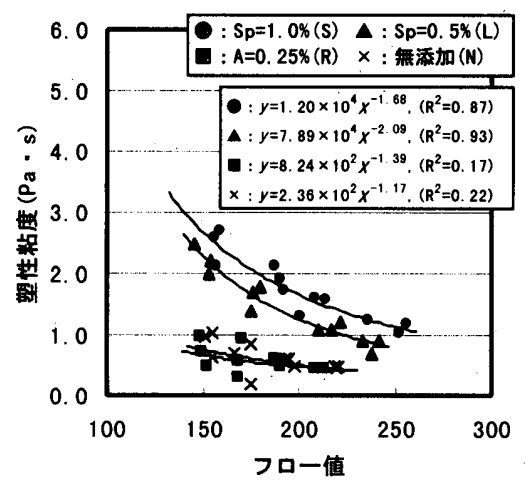

(b) 望性粘度

図 4.フロー値とレオロジー定数（降伏值、塑性粘度）の関係 
低下させたペーストのレオロジー量が大きくなることは予測され る。しかし減水剤を用いたペーストおよび減水剤無添加のペース トでは、ともにフロー値の大小によるレオロジー量の変化は小さ く、高性能 $\mathrm{AE}$ 減水剤の添加に比べて粘性の増大には効果的でな いことが分かった。一般に、セメントは水の中で機械的に相当激 しく攪汼しても十分には分散せず、数個から数十個の凝集体（フ ロック）を形成するとされている ${ }^{15)}$ これらのペーストでは、お そらく流体としての均質性に乏しい、すなわちセメント粒子の分 散性が不十分である可能性が高い。さらに、この場合には十分な 付着性が得られないため、回転粘度計による測定時にローターと ペーストの境界面にすべりを生じた可能性もある。

したがって、本実験で設定したポーラスコンクリートを対象と する低水セメン比領域では、セメント粒子を十分に分散させて安 定した流動性を得るために、とくに高性能 $\mathrm{AE}$ 減水剤の添加が望 ましいと考えられる。

\section{2 ポーラスコンクリートの性状}

ポーラスコンクリートに所定の空隙率を確保することにより、 構造上の強度が低下することは避けられない。すなわち、骨材を 実積率付近まで充填する（締め固める）場合には、ペースト量を 増加させて強度を確保するという手法は取ることができない。し たがって効果的に強度を確保するためには、ペーストの高強度化 や結合状態の最適化が必要になる。ペーストの高強度化は、通常 水セメント比を下げることにより可能であるが、結合状態の最適 化を図るためにはペーストをある程度流動化させ、かつ Funicular の第 1 領域を確保する必要がある。ここではペーストの流動化お よび締固めを十分に行うため表面振動機を用いることを前提とし て、減水剤の使用条件およびペースト量が、全空隙率および空隙 分布並びに圧縮強度に与える影響について検討した。

\section{（1）隇水剂の影響}

1) 空隙率

减水剂の使用条件により、セメント粒子の分散性や粘性に違い が生じることが3.1ペースト実験により明らかになった。そこで、

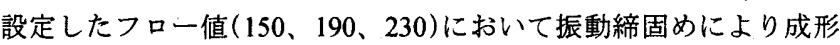
されるポーラスコンクリートの性状について調べる。設計空隙率 (全空隙率) は、緑化コンクリートなどに適した空隙率である $25 \%$ （表 3）とした。

締固め時に与えた振動エネルギーと全空隙率の関係を図 5 に示 す。図によれば、フロー值抢よび混和剤条件に関わらず、加振初 期に急激に空隙率が低下し、その後振動エネルギーが $90 \mathrm{kNm} / \mathrm{m}^{2}$ になるまで徐々に締め固められ、設計空隙率 (25\%) に漸近した。

\section{2 ) 圧縮強度}

振動エネルギーと圧縮強度の関倸を図 6 に示す。図によれば、 圧縮強度は振動締固めの進行に伴い增大する傾向を示した。これ は図 5 に示した空隙率の低下と密接に関係するものである。設定 したフロー值の範囲では、フロ一值が 230 と大きい場合、減水剂 の使用条件により圧縮強度には最大で $7 \mathrm{~N} / \mathrm{mm}^{2}$ 程度の差が生じた。 特に高性能 $\mathrm{AE}$ 減水剂を $1 \%$ 添加した調合( $\mathrm{S} 25: \mathrm{Sp}=1.0 \%)$ におい て強度発現が良好であった。本実験で設定した空隙率 $25 \%$ (ペー ス卜粗骨材容量比：P/G=29.7vol\%) では、比較的ペースト量が少な く、垂れによる影響はそれほど大きくないことから、この場合の
ポーラスコンクリリートの圧縮強度の差はペーストの圧縮強度の差 に起因するものと考えられる。

ポーラスコンクリートの強度性能は、また空隙率にも大きく左 右される。そこで、図7に空隙率と圧縮強度の関係を示す。加振 前の状態では概ね $50 \%$ 前後の空隙率を示し、圧縮強度も $5 \mathrm{~N} / \mathrm{mm}^{2}$ 以下である。その後振動締固めの進行に伴い、空隙率は低下し、 圧縮強度が増大寸る。このときの強度変化は、従来多くの研究で 表現されていた直線的なものではなく、空隙率の低下に伴い急激 に増大する傾向を示した。既往の研究で直線近似が行われた理由 は、設計空隙率に達した時点での空隙率と強度の関係に関するデ 一タが多く、設計空隙率の範囲も限られていたためである。また、 高性能 $\mathrm{AE}$ 減水剂を用いることで水セメント比を小さく設定でき、 所定の空隙率を要求されるポーラスコンクリートとして、強度面
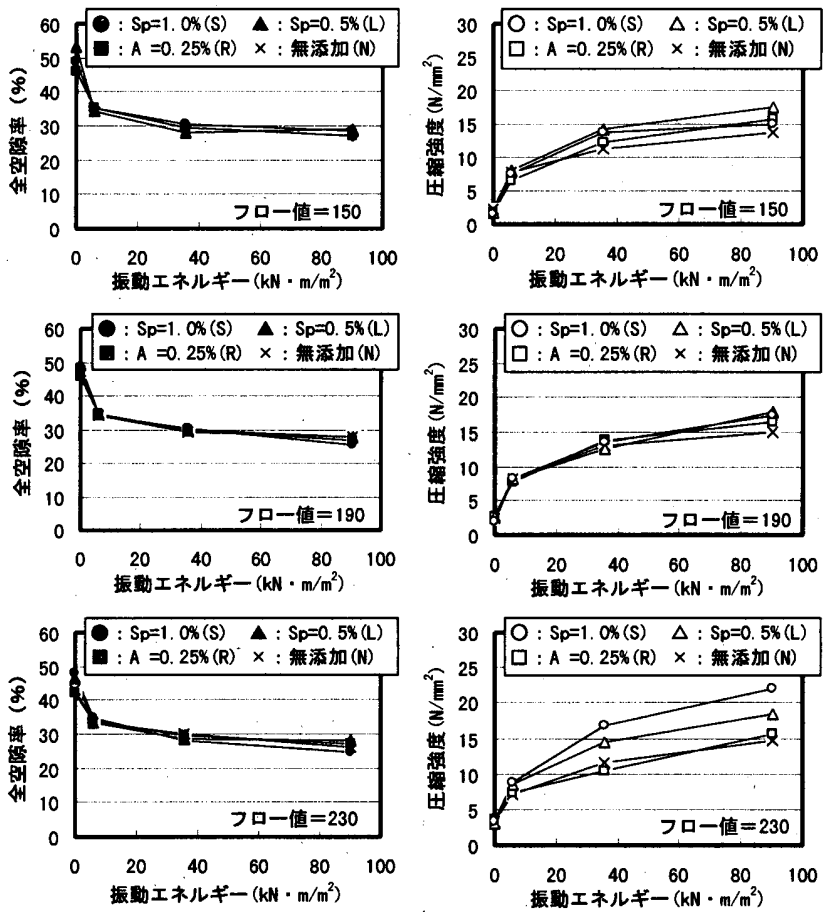

図 5 振動エネルギーと空隚率 の関係

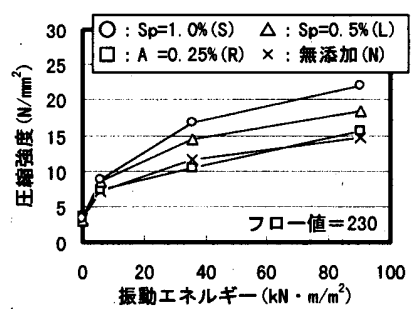

図 6 振動エネルギーと压縮 の関係

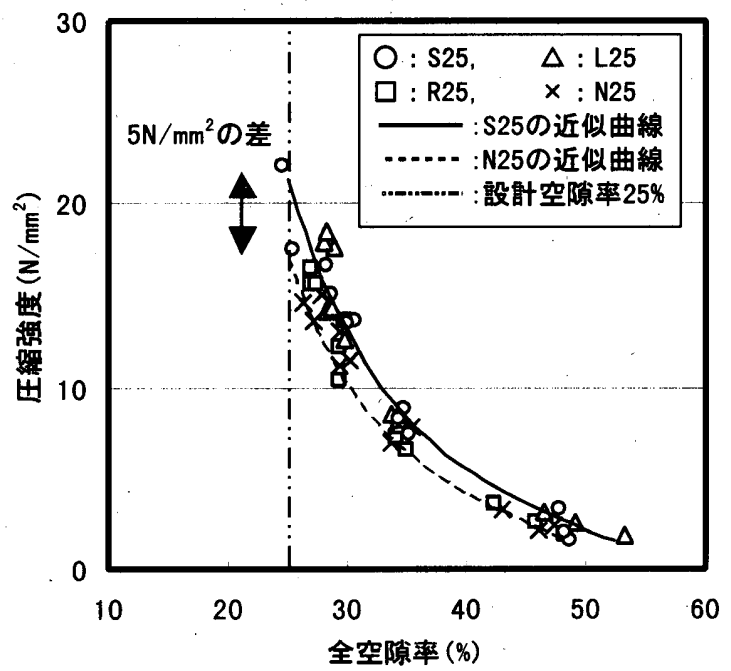

図 7 空隍率と圧縮強度の関係（減水剂の使用条件別） 
で極めて有利であることも判明した。なお図中には、設計空隙率

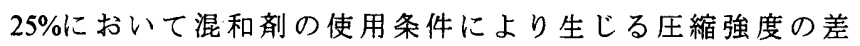
$\left(5 \mathrm{~N} / \mathrm{mm}^{2}\right.$ 程度) を示してある。

3）空隙分布

表面振動機により締固めを行う場合、振動エネルギーの伝播は 供試体の下層方向に減衰することが予測される。そこで硬化後の 供試体を上下方向（締固め方向）に3 等分し、空隙分布を調べた。 実測例を图 8 に、試験体記号を图 9 に示す。图 8 によれば、上下 方向の空隙分布は、振動エネルギーを与えない場合を除き、すべ てにおいて同方向に傾きを持つ傾向を示した。すなわち、空隙率 は振動力を直接受ける上層が最も小さくなり、一定の傾斜を持っ て下層ほど大きくなった。そして振動エネルギーの増加に伴い全 体に空隙率が小さくなる方向にシフトするが、締固め初期から終 了（振動エネルギー： $90 \mathrm{kN} \cdot \mathrm{m} / \mathrm{m}^{2}$ ) まで上下層の空隙率の差が概 ね $10 \%$ 程度に保たれたまま締固めが進行し、締固め終了時には、 3 層の平均值が所定の空隙率に近い值を示寸傾向が見られた。高 性能 $\mathrm{AE}$ 减水剤を用いた供試体((b)図)では、フロー值が大きいと 振動を直接受ける上層では所定の空隙率より小さい值を示した。 これはセメントの良好な分散性によりフロックが少なくなり、骨 材同士が直接接触することで、骨材の一部が破壊したためと考え られる。

なお、設計空隙率：25\%では、相対的にペースト量が少ない(ペ 一スト粗骨材比 : $\mathrm{P} / \mathrm{G}=29.7 \mathrm{vol} \%)$ ことから、フロー值 : 230 にお いてもペーストの垂れは生じなかった。

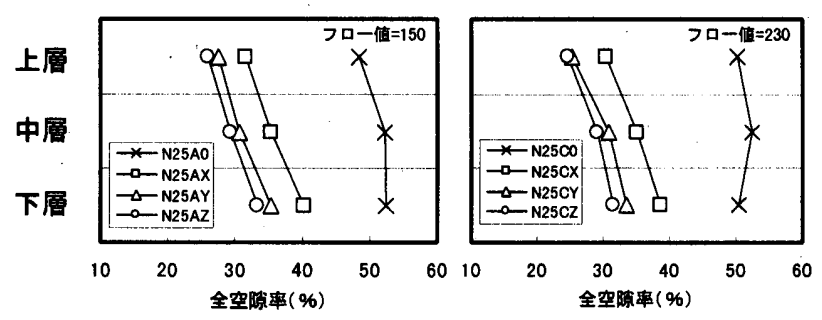

(a) 隇水刘無添加

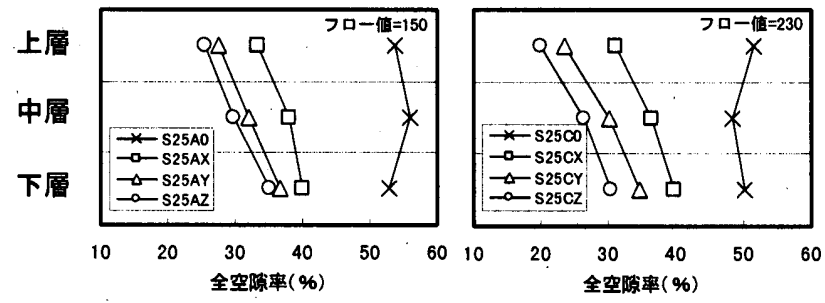

(b) 高性能AE減水剂1.0\%添加

图 8 空隌率分布の一例（設䀦空隙率25\%）

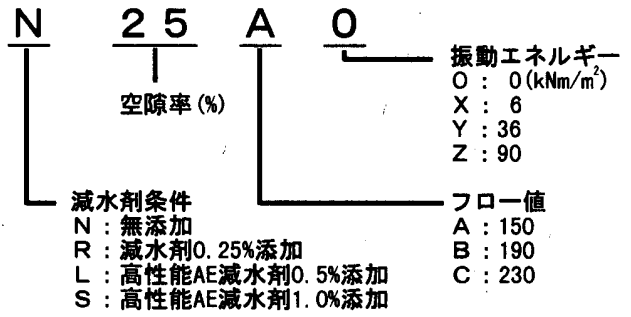

図 9 ポーラスコンクリートの試験体設定(作劉条件)の貺明
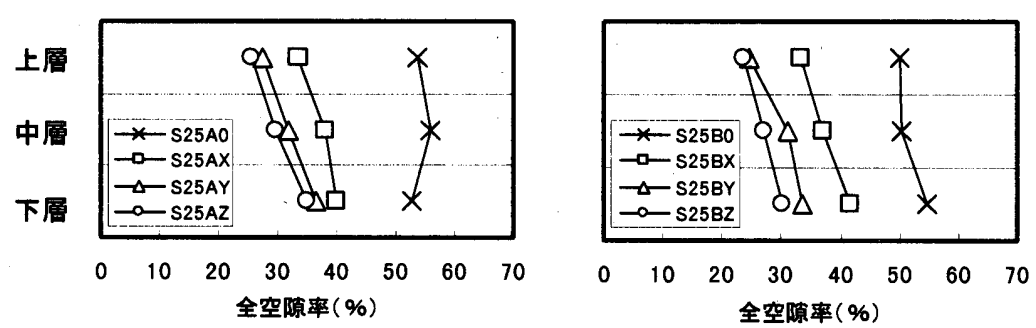

(a) 設計空隌率 $25 \%(P / G=29.7 \mathrm{vol} \%)$
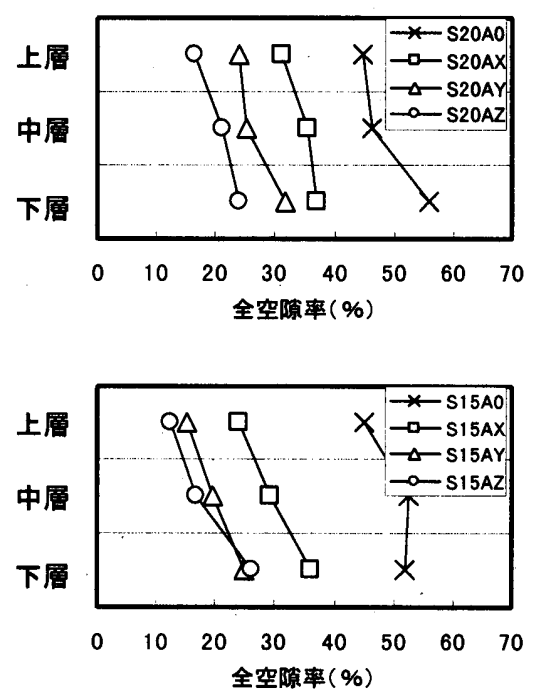

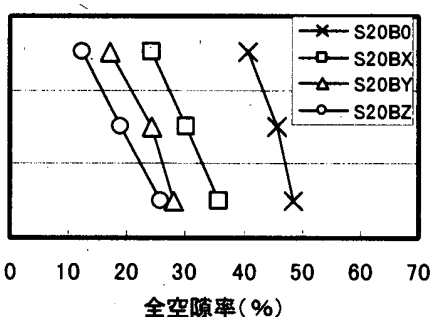

（b）設計空隚率20\% ( $P / G=38$. 2vol\%)

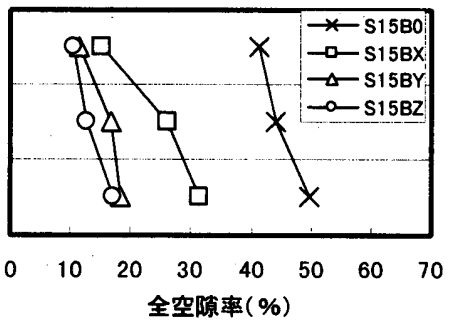

(c) 設毁空隙率 $15 \%(P / G=46.6$ vol\%)
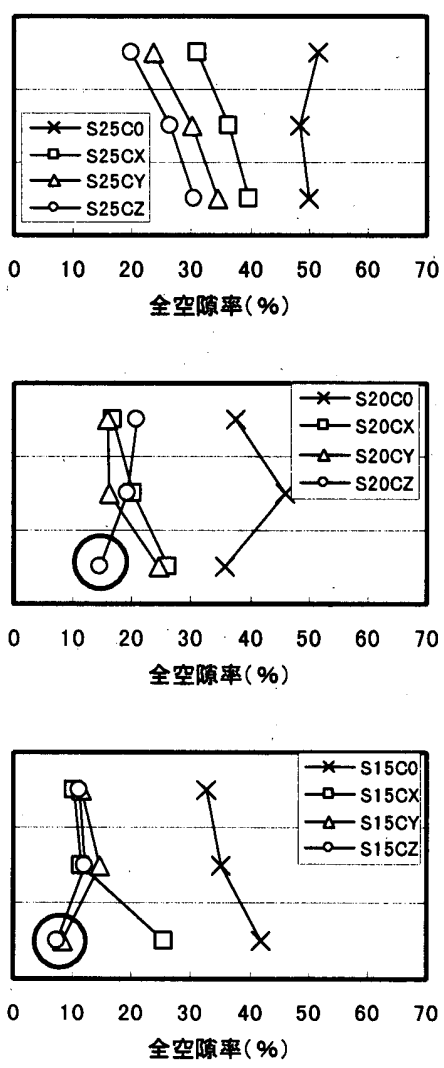

図 10 設計空隙率が異なるポーラスコンクリートの空隌率分布

(图中の○囲いは、ペーストの垂れによる空隌率の低下を示す) 


\section{（2）ペースト量の影暨}

ポーラスコンクリートの強度特性を支配するもう一つの要因と して、結合材の量が考えられる。結合材の多少は空隙率の大小に 直結し、既往の研究では空隙率と圧縮強度の関係は一定の傾きを 持つ直線近似で表現されてきた。しかし、空隙率は上記のように 締固めの程度によっても大きく変化する。

そこで、振動締固めの過程で、ペースト量の多少がポーラスコ ンクリートの諸物性に及ぼす影響について調べた。ここでは表 3 の調合から最も W/C の小さいS シリーズを選択し、ペースト量を 変化させることによって設計空隙率を $15 、 20 、 25 \%$ (ペースト粗 骨材比：P/G=29.7、38.2、46.6vol\%） とし、振動締固めを行った場 合の以下の性状について調べた。

(1)ペースト量が空隙分布に与える影響

(2)ペーストの量と流動性がペーストの垂れと圧縮強度に与える 影響

(3)ペースト量の違いが空隙率と圧縮強度の関係に与える影響

1) ペースト量が空隙分布に与える影響

設計空隙率（ペースト量）の異なるポーラスコンクリートの空 隙分布を图 10 に示す。設計空隙率 $25 \%$ ( ( a ) 図、P/G=29.7vol\%) の場合、設定したフロー值の範囲では加えたエネルギー量に応じ て一定の傾きを保ったまま締固めは進行するが、これよりペース 卜量が多い設計空隙率 $20 \%$ ( (b) 図、P/G = $38.2 \mathrm{vol} \%$ ) では、フロ 一值 230 において $90 \mathrm{kN} \cdot \mathrm{m} / \mathrm{m}^{2}$ の振動エネルギーで下層部に空隙 率の急激な低下と空隙分布の逆転が認められた（図中の○印）。さ らにペースト量が多い設計空隙率 $15 \%($ (c) 図、P/G = 46.6vol\%) で は、より小さい振動エネルギー $\left(36 \mathrm{kN} \cdot \mathrm{m} / \mathrm{m}^{2}\right)$ レベルから下層部 に空隙率の低下傾向が見られた。これは振動により流動化したぺ 一ストが下層部に移動したためである。実験で設定したフロ一值
の範囲では、骨材表面に付着したペーストは、静止時には保持さ れる程度の軟らかさである。しかし振動締固めにより、フロ一值 が大きい場合にはペースト量が多くなるほど流動化が激しくなり、 保持できるペースト量が低下する。すなわち、骨材表面に保持で きるペースト量は、ペーストの軟らかさと振動エネルギーの量に よって大きく影響を受けることを意味している。

2）ペーストの量と流動性がペーストの垂れと圧縮強度に与え る影響

ペーストの量が多くフロー值が大きい場合には、振動締固めエ ネルギー量が多くなるとぺーストは垂れてしまう。そこで振動エ ネルギーを $90 \mathrm{kN} ・ \mathrm{~m} / \mathrm{m}^{2}$ まで与えた供試体の底面に発生するぺー ストの垂れを、デジタルカメラに取り込み、観察・分析した。

图11 1 は、縦方向をフロー值、横方向を設計空隙率別に並べた ペーストの垂れの状況である。設計空隙率 $15 \%$ ではフロー值 190 以上でペーストの垂れが著しく、設計空隙率 $20 \%$ でもフロー值が 大きい 230 では著しいペーストの垂れが観察された。表 5 は、図 11 と同じ並びで供試体の圧縮強度を配置したものである。圧縮 強度に関してはペーストの垂れによる強度低下よりも、ペースト 量が少なくフロー值が小さいことによる強度低下の方が顕著であ った。この傾向は、筆者らの 5 号砕石を用いた締固め性状に関す る実験 》においても同様に見られており、このことは、骨材間を 架橋するペーストの連続性はペーストに垂れを生じる程度のほう が良好であることを示唆している。しかし、ポーラスコンクリー トとしての機能に問題が生じる可能性が高くなるため、著しい垂 れは避けなければならない。

以上のことから、ポーラスコンクリートの製造に最適なフロー 值は、設計空隙率の違い（ペースト量の多少）によって異なるこ とが分かった。すなわち、ポーラスコンクリートに用いるペース

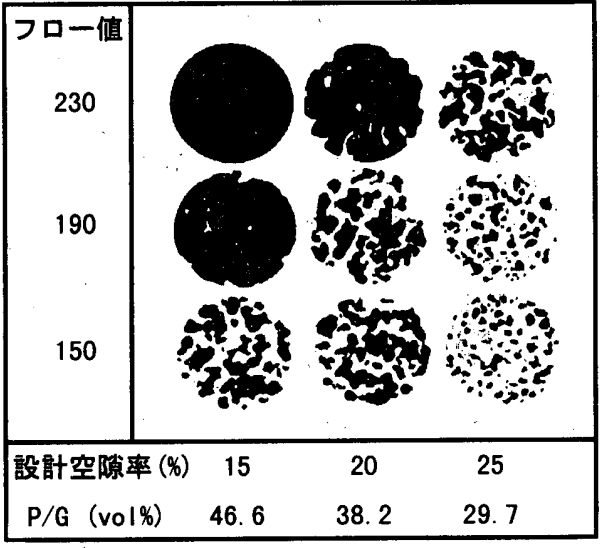

图 11 供試体底面の様子

表 5 空隌率別の圧縮強度

\begin{tabular}{|c|c|c|c|}
\hline フロー值 & \multicolumn{3}{|c|}{ 圧縮強度 $\left(\mathrm{N} / \mathrm{mm}^{2}\right)$} \\
\hline 230 & 38 & 31 & $--2 \underline{2}$, \\
\hline 190 & 44 & & 18 \\
\hline 150 & $-3,2$ & -29 & 15 \\
\hline 設計空隙率 ( & 15 & 20 & 25 \\
\hline
\end{tabular}

破線内：最適な性状のポーラスコンクリート

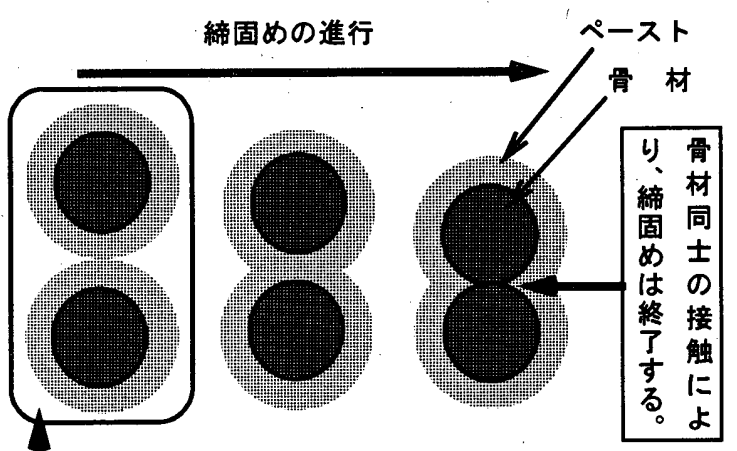

$(a-1)$

$(a-2)$

$(a-3)$

(a) 骨材間の結合状態

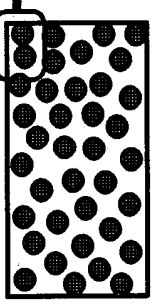

$(b-1)$

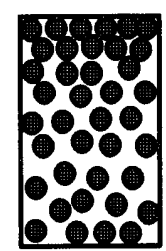

$(\mathrm{b}-2)$

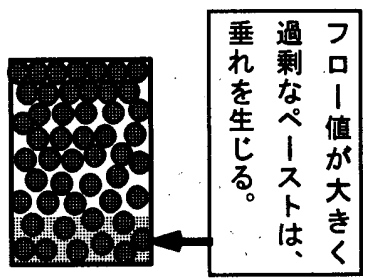

$(b-3)$ (b) 締固めの進行とペーストの垂れ

图 12 振動締固めの進行状況のイメージ 


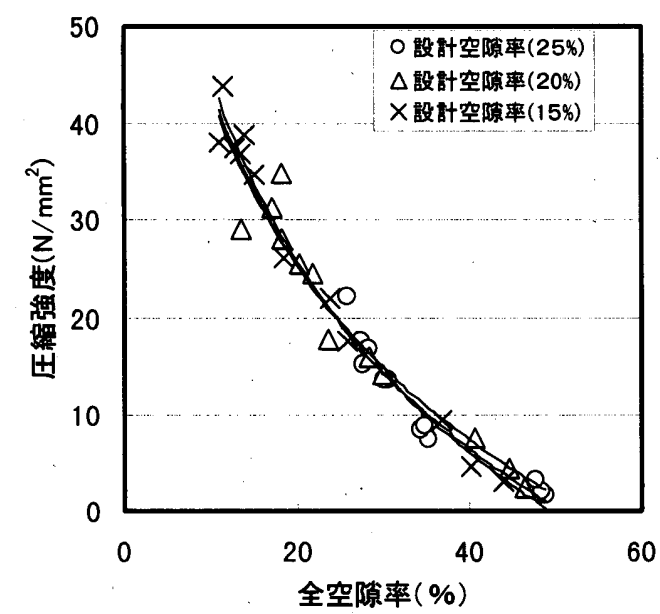

図 13 設計空腺率（ペースト量）と圧縮強度の関係

トの流動性に関して、種々の空隙率に適用できる唯一の条件は存 在しないことになる。本実験の範囲では、具体的な流動性の最適 值は、設計空隙率が $15 \%$ ではフロー值で 150 程度、20\%では 190 程度、 $25 \%$ では 230 程度であった（表 5 中の破線内）。

したがって、ポーラスコンクリートの製造に当たっては、その 使用目的により設定される空隙率に态じてフロー值を決定するこ とが肝要である。

なお、一連の締固め実験の結果から 1 層詰めによるポーラスコ ンクリートの振動締固めの過程を图 12 にまとめると、まず加振 前の状態では骨材に巻き付いたペーストは互いに接触する程度で 接触面積も僅かである（図 12 ：a-1、b-1）が、振動開始とともに 供試体の上層部から下層部にかけて順次締固めが進行し、ペース トの变形を伴いながら接触面積が徐々に増加する(図 12 : a-2、 b-2)。そして最終的には上下層に空隙率差を保ちながら、隣り合 う骨材同士が接触するまで締固めは進行する(图12：a-3、 b-3）。このときペースト量が多く垂れが著しい場合には、供試 体の底部に垂れによって生じたペーストの密実な層が形成される。

3）ペースト量の違いが空隙率と圧縮強度の関倸に与える影響

图 13 に、設計空隙率 $(15 、 20 、 25 \%)$ 別に空隙率と圧縮強度の 関係を示す。各設計空隙率には 3 種類のフロ一值 $(150 、 190 、 230)$ がすべて含まれている。図によれば、フロー値の違いによるバラ ツキは多少あるものの圧縮強度と空隙率との間にはある一定の関 倸があり、空隙率は締固めの程度に応じて最大 $50 \%$ 程度から設計 空隙率付近まで低下寸る傾向を示した。この傾向は減水剤の使用 条件の異なる図 7においてもほぼ同様である。ここで、图 7 の減 水剤の使用条件の違いは、近似曲線を上下にシフトする、すなわ ち強度性能の高低に関わるものであるが、ペースト量の違いは、 結局、最終的に到達する空隙率の違いであって、圧縮強度と空隙 率の関係は、ひとつの近似曲線で表現されることが分かった。

（3）ポーラスコンクリートの圧縮強度と空隙率の関係式

ポーラスコンクリートの強度について、脆性多孔材料の空隙率 と強度に関する Ryshkewitch ${ }^{16)}$ と Duckworth ${ }^{177}$ により提案された式 [2]を参考に指数関数による数式表示を行った。

以下に脆性多孔材料の圧縮強度を表す一般式及び実験式を示す。

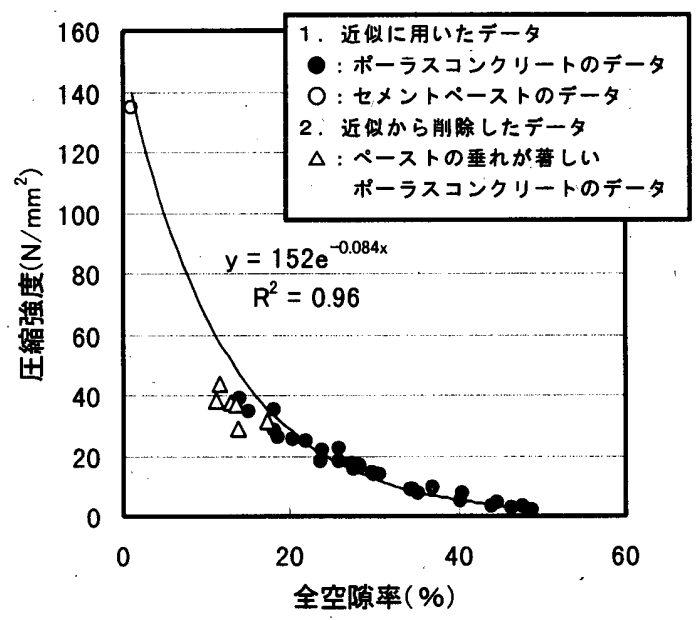

図 14 全空隙率と圧縮強度の近似例

$$
\begin{aligned}
& \sigma=\sigma_{0} \exp (-\mathrm{bP}) \\
& \text { ここに、 } \sigma: \text { : 多孔体の圧縮強度 }\left(\mathrm{N} / \mathrm{mm}^{2}\right) \\
& \sigma_{0}: \text { 空隙率が } 0 \text { の時の圧縮強度 }\left(\mathrm{N} / \mathrm{mm}^{2}\right) \\
& \mathrm{P}: \text { : 空隙率 }(\%) \\
& \mathrm{b}: \text { : 実験定数 }
\end{aligned}
$$

用いたデータは、図 13 の全データにペーストの強度(図 14 中 の記号：○)を追加し、かつペーストの垂れが著しく均質性が確保 されなかったポーラスコンクリートのデータを削除(図 14 中の記

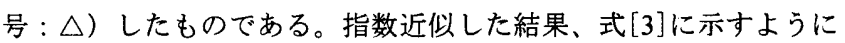
高い相関関係が得られた。用いたデータおよび近似線は图 14 に 併例示してある。

$$
\begin{aligned}
& y=152 \exp (-0.084 x) \\
& R^{2}=0.96 \\
& \text { ここに、 } y \quad: \text { ポーラスコンクリートの圧縮強度 }\left(\mathrm{N} / \mathrm{mm}^{2}\right) \\
& x \quad: \text { 全空隚率 }(\%)
\end{aligned}
$$

ここで、ペースト強度を骨材を含むポーラスコンクリートと同 時に取り扱うことは、一般には若干無理があると考えられる。し かしペーストの強度が拉よそ $135 \mathrm{~N} / \mathrm{mm}^{2}$ であるのに対して、用い た䂶石の圧縮強度が $150 \mathrm{~N} / \mathrm{mm}^{2}$ 程度であり、それほど大きな違い がないことや骨材とペーストの界面にブリージングが発生しない ことなどから、極端な界面破壊や骨材の先行破壊はなかったと判 断し、ここではペースト強度を加えて近似曲線を求めた。

ポーラスコンクリートの強度を表す実験式については、わずか に中澤ら ${ }^{18}$ がコンクリートの空気量と強度の関係から推定した例 がある。筆者らの実験では、結合材強度も含めて近似し、脆性多 孔材料一般に適用できる指数関数式により表現できることを示し た。

以上より、骨材の品質やペーストによる架橋が十分に確保され ていれば、ペースト量と締固めの程度に関わらず、ポーラスコン クリートの強度特性を広範囲の空隙率に対して表現・推定できる 可能性が示唆されたといえる。

（4）ポーラスコンクリートの圧縮強度に及ぼす諸要因の影䈏 骨材条件を同一にした場合について、これらの結果をもとに、 


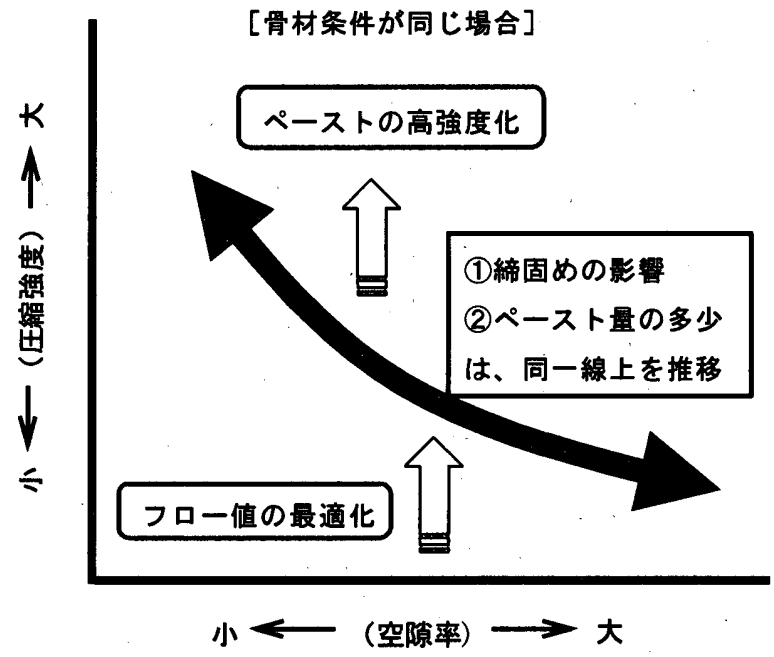

\section{图15 ポーラスコンクリートの強度性能に与える 諸要因の影䡒 (イメージ図)}

ポーラスコンクリートの圧縮強度に与える諸要因の影響について まとめれば、図15のイメージ図のようになる。

したがって、ポーラスコンクリートの強度性能を向上させるた めには、フロー值の最適化とペーストの高強度化が重要な要因と なる。

\section{4. まとめ}

ポーラスコンクリートの製造時に重要な要因となる振動締固め 性状について、ペーストのフレッシュ性状と関連づけて検討した。 その結果、以下のことが明らかになった。

(1)混和剤の種類に関わらず、ペーストの流動性は、270 秒以上の 練混ぜにより安定することが分かった。

(2) ポーラスコンクリートに用いられる低水セメント比域 $(W / C=20$ 〜 25\%)のペーストでは、高性能 AE 减水郕を使用するのが効 果的である。通常の減水郕では十分な効果を期待できない。

(3)表面振動機により、直接締固め作用を受ける上層部と受けない 下層部では概衫 $10 \%$ 程度の空隙率の差を生じた。

(4)調合が同一の場合、ポーラスコンクリートの空隙率と圧縮強度 の関係は、締固め程度に関わらず一つの曲線上に存在する。し たがって所定の空隙率における強度性能の向上という点では、 効果がないといえる。

（5)ペースト量および振動エネルギー量が多いほど垂れを生じやす いが、適切なフロー値を設定すれば垂れを発生させずに締固め が可能である。このとき圧縮強度は最も高くなる傾向にある。 本実験では、設計空隙率 $15 \%$ ではフロー值を 150 程度に、20 \%では 190 に、25\%では 230 に設定することでポーラスコン クリートとしての良好な強度が得られた。

(6) ポーラスコンクリートの圧縮強度は、空隙率と空隙率 0 の時の 圧縮強度を説明変数とする多孔質材料の強度式により表現でき る可能性が示唆された。

今後、製造条件が異なる場合のポーラスコンクリートの強度予 測について、さらに検討するため、骨材粒径やペースト強度の影 響などに関して、より広範な実験を行う予定である。

\section{謝 辞}

本研究を進めるに当たり、終始実験に協力いただいた力丸ゆか りさん（前三重大学 4 年生）に深謝いたします。さらに試料を提 供してくださった、エフ・ピー・ケー（株）名古屋営業所，小栗 敏氏、（株）松阪興産魚見工場 下村圭二氏に謝意を表します。

\section{参考文献}

1）エココンクリート研究委員会報告書：日本コンクリート工学協会， 1995.11

2）「自然環境との調和を考虑したエココンクリートの現状と将来展望に関 するシンポジウム」論文報告集，日本コンクリート工学協会，1995.11

3）玉井元治：連続空隙を有する固化体の透水性，セメシト技術年報，第 42 巻, pp. 591-594, 1988.12

4）吉森和人・藤原浩巳・伊藤修一・岡本享久・下山善秀 : 植生ポーラスコ ンクリートの製造と耐久性に関する実験的研究,「自然環境との調和を考 虑したエココンクリートの現状と将来展望に関するシンポジウム」論文 報告集，日本コンクリート工学協会, pp. 39-46, 1995.11

5）湯浅幸久・村上和美・前川明弘・畑中重光：ポーラスコンクリートの製 造方法に関する基磷的実験, コンクリート工学年次論文報告集, Vol. 21 , No. 1 , pp. $235-240,1999.6$

6）柳橋邦生・米澤敏男・安藤慎一郎・楠田建夫：倉吉才ヶ崎護岸における 緑化コンクリートの施エ，コンクリートエ学，Vol. 37,№. 2,pp. 30-34, 1999. 2

7）湯浅幸久・別府智子・宮本高秀・畑中重光：セメントペーストの流動 性がポーラスコンクリートの振動締固め性状に及ぼす影響, コンクリ 一个工学年次論文報告集，Vol. 23，No. 1，pp. 133-138，2001.7

8）添田政司・大和竹史・江本幸雄：ポーラスコンクリートへの再生骨材の 適用性に関する実験的研究，コンクリート工学年次論文報告集，Vol. 20, No. 2, pp. 1117-1122, 1998.6

9）平岩 睦・田中清人・谷川恭雄・森博嗣 : ポーラスコンクリートの調合 設計法に関する基喽的研究, コンクリート工学年次論文報告集, Vol. 23, No. 1, pp. 121-126, 2001.7

10）玉井元治：ポーラスコンクリート技術の現状と将来性, TAIHEIY0 CEMENT TECHNICAL INFORMATION[CEM'S], №. 6, pp. 2-7, 2000.7

11）柳橋邦生・米澤敏男・佐久間護・池尾陽作：緑化コンクリートに関する 研究および施エ，コンクリート工学年次論文報告集，Vol. 16，№. 1, pp. $871-876,1994.6$

12）二三島直生・谷川恭雄・森博嗣・黒川善幸・寺田謙一・服部俊範：せん 断ボックス試験による高濃度サスペンションのレオロジー性質に関す る実験的研究, 日本建築学会構造系論文集, No. 528, pp. 13-19, 2000.2

13）フレッシュコンクリートの流動特性，コンクリートポンプエ法施工指針 ・同解説, pp. 192-236, 1994

14）超硬練り研究委員会報告書, 日本コンクリート工学協会, pp. 155-162, 1998.6

15）新・コンクリート用混和材料，シーェムシー，1989.7

16) E. Ryshkewitch, Compression Strength of Porous Sintered Alumina and Ziluconia, Jour. of the Amer. Ceramic Society, Vol. 36, No.2, 1953

17.) W. Duckworth, Discussion of Ryshkewitch Paper, Jour. of the Amer Ceramic Society, Vol.36, №. 2, 1953

18）張 日紅・中澤隆雄・新西成男：ポーラスコンクリートの空隙率が圧 縮強度と応カーひずみ関倸に及ぼす影響，セメント・コンクリート論 文集，No. 51，pp. 864-869，1997

（2001年 9 月 10 日原稿受理， 2001 年11月 8 日採用決定 